\title{
nature
}

\section{Britain hazards embryo research}

\section{The British government's much-delayed response to the Warnock Committee's report on the manipu- lation of human embryos would unwisely let parliament decide whether research is to be allowed.}

THAT there should be restraints of some kind on the manipulation of human embryos has been clear for at least the past two decades. In the past five years, with the development of techniques for transferring artificially fertilized ova to human uteri, the urgent need has been not merely to draw a line between the permissible and the forbidden, but also to devise a mechanism for administering the legal framework of restraint. Given the contributions of British scientists to the practice of in vitro fertilization, the British government inevitably finds itself among the first in the legislative field, after the state of Victoria in Australia. Does that explain why it has taken more than three years for the government to describe in general terms the legislation it plans for the permanent regulation of the manipulation of human embryos, both in the treatment of infertility and otherwise, in research for example (see p. 409)?

The delay since the publication of the Warnock report, which the government's proposals broadly follow, has been particularly intolerable to practitioners and to the members of the Voluntary Licensing Authority, set up by the Medical Research Council and the Royal College of Obstetrics and Gynaecology, who have discharged with ingenuity and distinction the thankless task of regulating without statutory authority. It will seem to them a poor reward that the government has decided not to make up its mind on the question whether research with human embryos will be allowable under any circumstances, but instead to take pot luck with a free vote in the House of Commons.

That does not, of course, imply that members of parliament cannot be trusted to make rational decisions. Rather, it is the case that the coming year is likely to be over-charged with controversy over the rights and wrongs of British abortion law, chiefly because Mr David Alton, a Liberal member of the House of Commons, has introduced a bill to reduce the legal limit on the gestation time at which fetuses may be legally aborted (which requires two physicians to certify that the putative mother's physical or mental health would otherwise be impaired). Mr Alton proposes that the legal limit should be reduced from 28 weeks to 18 weeks, which is probably sensible; there is room for argument about the numbers, but there is no doubt that the technology for the preservation of fetuses born prematurely has improved in the past 25 years, while there have also been many improvements of the diagnosis of pregnancy, and changing manners have diminished the likelihood that pregnant women will for long be innocent of their condition.

\section{Trouble}

The trouble is that Alton's innocuous bill is certain also to provide an opportunity for those who hold that abortion should not be permitted in any circumstances to re-run the arguments that echoed round the British parliament in the 1960s. It is inevitable that this old controversy will inflame the argument about embryo research that will follow. Indeed, it is also likely that the prospect of legislation on embryo research will confuse the issue about the abortion law; there are many people in the House of Commons eager for a chance to rattle the threat that devilish experiments with human embryos are around the corner to support the case that abortion should be forbidden. That is why it would have been much better if the government had put its weight behind a proposal that embryo research should be allowed under certain conditions.

Why is that important? The simple reason is that there is much of potential benefit to be learned not merely about the development of the human embryo, and the reasons why the course of development is not always within the norm, from carefully regulated embryo research. The causes of spina bifida and other congenital malformations of the spinal tract, for example, are likely to be accessible to studies of human embryos in the few weeks after fertilization. The better understanding of the sequence of development of human organs would be valued, not merely for its own sake but as a foundation for later studies of teratogenesis and natural uterine influences on development.

\section{Research}

There is also a sense in which the government's proposals entail that there should be at least some research with embryos; the draft clause the government plans to introduce if parliament decides to prohibit research would forbid all procedures with embryos other than those intended to assist their transfer to a uterus or "to ascertain the suitability of that embryo for the intended transfer". The genetic analysis of early embryos would be a natural goal, but one that will not be attainable without further research, which will no doubt be carried through somehow, somewhere and at some time. So the British government seems to be proposing that, if parliament decides that research will not be allowed under any circumstances, British practitioners will have to rely for the techniques for ascertaining "suitability" on work carried out elsewhere. Does that make sense?

Why all the fuss about embryo research? The government's white paper notes (in an appendix) the sharp difference of opinion between those who respectively allow and disallow embryo research that the former "would not generally accept the proposition that the human embryo should, from the point of conception, be regarded as having the same full human status as a child". The latter, the white paper says, hold that the eventual destruction of embryos, a necessary consequence of embryo research, "is tantamount to murder". This apposition can only sharpen the government's own difficulties in the months ahead.

The truth is that both sides in the argument agree that embryo research must at the very least be regulated because human embryos are potentially human beings, and are deserving of respect on that account. And while a one-day embryo cannot hope to survive without the benefit of a human uterus, there are many among the supporters of embryo research who would agree that the status of such an embryo is not very different from that of, say, an 18-week fetus; both are potentially human beings. The case for a continuation of research with human embryos does not rest on the assertion that early embryos are otherwise, but on the belief that the social benefits of continuing research would be considerable and the conviction that the manipulation of small clumps of cells can be done without raising in the minds of practitioners the sense of having been killing people. Ironically, abortion (also justified largely on social grounds) is more evidently offensive. 